\title{
VARIATION IN PHENOLOGY, GROWTH, AND WOOD ANATOMY OF TOONA SINENSIS AND TOONA CILIATA IN RELATION TO DIFFERENT ENVIRONMENTAL CONDITIONS
}

\author{
Ingo Heinrich ${ }^{1}$ and John C. G. Banks \\ School of Resources, Environment, and Society, Australian National University, Canberra, Australian Capital Territory 0200, Australia
}

\begin{abstract}
Tree-ring proxy data from subtropical to tropical Australasia are valuable though rare sources for climate reconstructions. Toona sinensis (A. Juss.) M. Roem. and Toona ciliata M. Roem. occurring naturally in this region are among the most promising tree species for future tree-ring research. However, little is known about their phenological behaviors and the influence of environmental conditions on their intraseasonal growth and wood anatomical properties. Growth experiments were conducted on young trees of both species to investigate their responses to different treatments. The results show that phenology and growth were adjusted according to the severity of the treatments. Restricted growth conditions often caused longer leafless periods, shorter flushes of leaves, and decreased height and diameter growth increments, and they resulted in more but smaller vessels. Under optimum conditions, T. ciliata did not become leafless, had multiple leaf flushes, sustained growth throughout the experiment, and did not form a tree-ring boundary. All other specimens of both species entering leafless or at least semileafless periods formed one tree-ring boundary during the experiment. The growth reaction was more distinct in the latewood than in the earlywood, in extreme cases suppressing the latewood totally. Although the experiment was conducted on young trees and hence should not simply be generalized and applied to adult specimens, the results indicate that both species are well suited for reliable future dendroclimatological investigations. Such studies need to pay attention to possible missing rings in the young parts of tree-ring series.
\end{abstract}

Keywords: growth experiment, tree-ring boundary, deciduousness, dormancy, vessel characteristics.

\section{Introduction}

Toona sinensis (A. Juss.) M. Roem. and Toona ciliata M. Roem. appear exclusively in Australasia. Toona ciliata extends naturally from eastern Pakistan and India through southeast Asia and southern China and through Hainan Island to the Philippines and eastern Australia. Natural populations of $T$. sinensis occur in southeast Asia from India and Nepal eastward through China, Burma, and Thailand to Malaysia and Indonesia. The species are similar in their habitat demands; that is, both are present in tropical to subtropical highland forests. In Asia, both species grow in the same forest types, but they occupy different niches, with T. ciliata preferring the wetter locations with richer soils. Both species grow best under a uniform summer rainfall regime but at most locations have to adjust to a dry season during the winter months. In comparison to T. ciliata, T. sinensis can flourish on a wider range of soil types and is slightly more frost and drought hardy (Floyd 1979; Edmonds 1995; Edmonds and Staniforth 1998; Boland et al. 2002).

Both species are susceptible to attacks by shoot borers (Hypsipyla robusta and Batocera horsfieldi), which bore into

\footnotetext{
${ }^{1}$ Author for correspondence; current address: Department of Geosciences and Geography, University of Fribourg, 1700 Fribourg, Switzerland; e-mail ingo.heinrich@unifr.ch.
}

the new shoots and excavate a hollow, causing the growing tip above to die. The attack on young trees can destroy the form, result in partial defoliation, suppress growth, and even kill them. It is probable that at least several generations of the insect would occur each year, but long-term fluctuations of its populations have not been reported. In contrast to insect infestations of other tree species, for example, in Europe, the effects of the Toona shoot borers on stem growth and wood anatomy are not known (Mo et al. 1997a, 1997b).

The causal connections between environmental conditions, phenological behavior, cambial periodicity, and tree growth are relatively well known for tree species from temperate regions of the Northern Hemisphere. However, for tropical tree species from the Southern Hemisphere, comparable data are rather scarce. In Indonesia, first studies examined the phenology and physiology of local and exotic tree species (Volkens 1903; Simon 1914; Coster 1923, 1927, 1928). Coster (1928) concluded that the tendency of rhythmic growth is genetically fixed but the periodicity can be altered by changing the growing conditions. These early results were confirmed by Fahn and Werker (1990) and Koriba (1958), working on Eucalyptus camaldulensis Dehnh. and Acacia dealbata A. Cunn., respectively. In contrast, Daubenmire (1972) observed no differences in the phenology of phreatophytes growing at different locations with diverse site conditions.

Several studies report that the phenological behavior and growth periodicity of tropical trees are influenced by different environmental factors, including day length (Njoku 1963, 
1964; Daubenmire 1972; Frankie et al. 1974; Breitsprecher and Bethel 1990; Rivera and Borchert 2001), internal water status, soil moisture, and relative humidity (Reich and Borchert 1984; Wright and Cornejo 1990; Williams et al. 1997; Myers et al. 1998; Schöngart et al. 2002), thermoperiodic mechanisms (Alvim 1964), and temperature (Paliwal and Prasad 1970; Paliwal et al. 1975; Ghouse and Hashmi 1979; Iqbal and Ghouse 1982; Ajmal and Iqbal 1987).

Annual tree-ring formation relies on a shift of the cambium into dormancy once a year (Strasburger et al. 2002). In the tropics, saplings of many tree species remain evergreen and show continuous growth for several years. With increasing size, the trees start to shed their leaves during the dry season and become dormant for increasingly longer periods (Coster 1928; Chowdhury 1961; Fahn et al. 1981; Tomlinson and Longman 1981; Priya and Bhat 1999). While deciduousness is an obvious sign of dormancy, ring formation might also be related to bud flushing, as has been shown for more than a dozen tree species in India (Iqbal 1981) and Africa (Amobi 1972) that usually produce several growth rings per year, often in phase with multiple bud flushes. Furthermore, Amobi $(1973,1974)$ found that the initiation of the cambial activity was correlated with bud break and leaf formation. While in seedlings the number of tree rings did not tally with the total number of bud flushes, the numbers corresponded well in the wood formed by older cambium. Alternatively, Tomlinson and Craighead (1972) described that Swietenia macrophylla King underwent several periods of leaf flushing each year but tended to produce strictly annual rings. In a similar study in India, Chowdhury (1958) counted up to four flushes of extension growth but only one period of radial growth and suggested that extension and radial growth can be separate processes even within the same tree.

There is clear evidence in the literature proposing that wood anatomy is a good indicator of different environmental conditions. For example, in an extensive study, Carlquist (1966) examined 328 different Compositae species and discovered general trends in wood anatomical properties, for instance, that the vessel numbers increased and their diameters decreased in a transition from mesic to arid environments. Similar results were reported by Baas (1973), BarajasMorales (1985), Wilkins and Papassotiriou (1989), Wheeler and Baas (1993), Lindorf (1994), and Woodcock and Ignas (1994). Additional variances because of different environmental conditions within wide latitudinal ranges were found in the distinctiveness of the growth rings and parenchyma bands delimiting individual rings (Dadswell and Ingle 1954) and in the porosity of the tree-ring structures changing from ring-porous to diffuse-porous (Liphschitz and Waisel 1970; Priya and Bhat 1999).

Both $T$. ciliata and $T$. sinensis also exhibit large latitudinal distributions, and thus it can be expected that their wood anatomies also vary because of shifts in the environmental conditions of the respective climate zones they grow in. Several examples of false rings and difficult ring-boundary zones, for instance, zones of very narrow tree rings in $T$. ciliata, have been presented by Heinrich and Banks (2006) (fig. 1). Since tree-ring analysis of the two species is planned, it seems necessary to first conduct growth experiments to examine the influence of the environment on the wood anatomy and the periodicity of the two Toona species. Our study tries to cover all aspects of the relationship between phenology, cambial activity, tree-ring structure, and wood anatomy, accounting for the fact that the ecology of the two species is poorly understood.

\section{Material and Methods}

A growth experiment with six groups was set up on December 5, 2001, in Canberra to examine the growth responses of trees to different stress factors imposed by the treatment (table 1). Each group $\mathrm{X}_{1}-\mathrm{X}_{6}$ consisted of six 2-yrold individuals with heights and diameters of ca. $1.3 \mathrm{~m}$ and $1.5 \mathrm{~cm}$, respectively. Each group contained four specimens of Toona sinensis (plants 1-24) but only two of Toona ciliata (plants 25-36) because of the limited availability of suitable T. ciliata seedlings. All groups were kept in glass houses with an automatically regulated optimum temperature of ca. $25^{\circ} \mathrm{C}$. Only group $\mathrm{X}_{4}$ was positioned outside under thin shade cloth to expose the plants to seasonal temperature variations and to filter detrimental effects of direct sunlight. The plants in the optimum water groups were watered at least every day, in summer two to three times a day. In comparison, in the minimum water group, to imitate a much drier environment, the trees were only watered once every 2-7 d, depending on the season. Groups $\mathrm{X}_{1}-\mathrm{X}_{4}$ received an optimum supply of nutrients by application of slow-release fertilizer tablets Scout Osmocote (nitrogen 18\%, phosphorus 4.8\%, and potassium $9.1 \%$ ), while groups $\mathrm{X}_{5}$ and $\mathrm{X}_{6}$ did not obtain any nutrition, in order to simulate poor soil growth conditions. Most of the time, group $\mathrm{X}_{3}$ was treated exactly like optimum group $\mathrm{X}_{1}$, but in the middle of the growing period, the plants were not watered for $11 \mathrm{~d}$. Optimum watering was resumed after the trees started to shed leaves and leaves showed
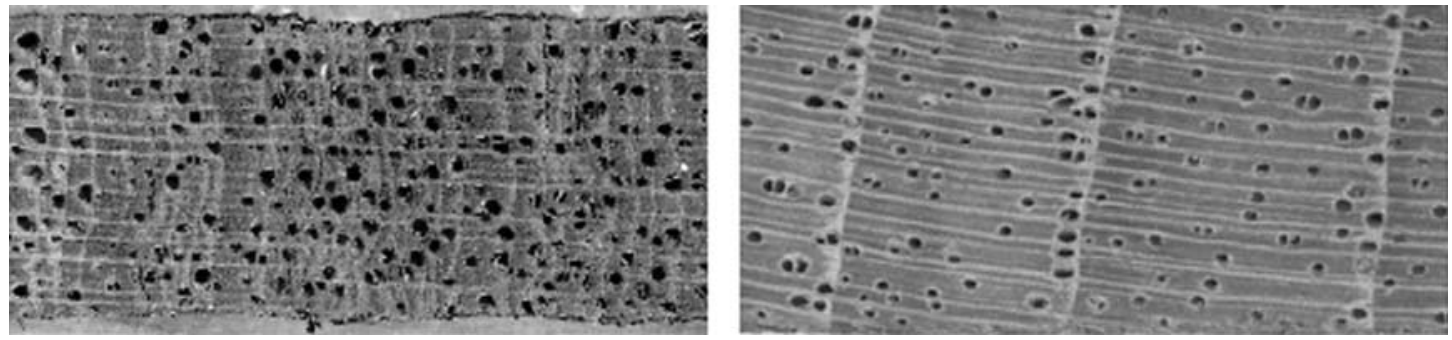

Fig. 1 Examples of narrow (left) and wide (right) rings in Toona ciliata. 
Table 1

Treatment Groups in Growth Experiment

\begin{tabular}{lcc}
\hline Treatment & Fertilizer & No fertilizer \\
\hline $\begin{array}{l}\text { Optimum water } \\
\text { and optimum } \\
\text { temperature }\end{array}$ & $\mathrm{X}_{1}$ (trees 1-4, 25-26) & $\mathrm{X}_{5}$ (trees 17-20, 33-34) \\
$\begin{array}{l}\text { Minimum water } \\
\text { and optimum } \\
\text { temperature }\end{array}$ & $\mathrm{X}_{2}$ (trees 5-8, 27-28) & $\mathrm{X}_{6}$ (trees 21-24, 35-36) \\
$\begin{array}{l}\text { No water for 11 d } \\
\text { and optimum } \\
\text { temperature }\end{array}$ & $\mathrm{X}_{3}$ (trees 9-12, 29-30) \\
$\begin{array}{l}\text { Optimum water } \\
\text { and minimum } \\
\text { temperature }\end{array}$ & $\mathrm{X}_{4}$ (trees 13-16, 31-32) \\
\hline
\end{tabular}

distinct signs of wilting, indicating that the treatment had imitated well conditions experienced during natural droughts or shoot borer attacks.

\section{The Pinning Method}

The pinning method was first employed and described by Mariaux (1967) and Wolter (1968). They found that an injury of the cambium, applied by a nail, needle, or scalpel, resulted in the formation of aberrant parenchyma-like cells that were permanently retained, recognizable, and datable within the growth zone. Kuroda and Shimaji (1984) demonstrated for the first time that the pinning method also works for hardwoods on an intraseasonal timescale. They found that hardwood species started to form wound tissue even faster than softwood species. Because of a less delayed response time, dating of injury events would be more accurate in hardwood species. The findings were supported by the application of the method to tree-ring analysis (Kuroda and Shimaji 1985; Kuroda 1986; Shiokura 1989; Nobuchi et al. 1995; Sass et al. 1995; Fujii et al. 1999; Bauch and Dünisch 2000).

For this study, small pins were inserted into the stem from the four cardinal points in order to induce minute wound tissue discernible as a useful marker during the subsequent wood anatomical analysis. In the course of the experiment, the plants were pinned quarterly, on February 5, May 7, August 3, and November 12, 2001, and pinning areas were marked with different colors for later identification. The quarterly pinning areas were located adjacent to each other along the stems, preventing interference between the pinning zones. Initial measurements of plant heights and diameters were taken and were repeated every quarter parallel to the application of the pinning. The phenology and general condition of the plants were recorded weekly. On January 29, 2002, the experiment was terminated by crosscutting the stems close to the different pinning areas.

\section{Preparation of Samples for Microscopy and Digital Imagery}

For further microscopic analysis, thin transverse sections of the consecutive pinning areas were cut. A Zeiss Axioskop equipped with a digital camera was utilized to conduct light microscopy. First, the samples were examined for possible tree-ring boundaries and false rings formed during the experi- ment. Tree-ring boundaries were delimited by a light-colored line of parenchyma cells and a zone of large earlywood vessels, visible to the naked eye. These observations were then combined with weekly phenology data, that is, occurrences of semileafless (ranging from only a few leaves to almost all leaves shed) and leafless (all leaves lost) periods and leaf flushes collected during the experiment. Second, the images of the pinning areas were imported to the digital imagery software ImageJ (supplied by the National Institutes of Health). The distance from each wound tissue to the cambium was measured at four randomly chosen radii. Along these radii, outside the wound tissue zones, the numbers and diameters of all individual vessels that were cut or touched by the radii were measured manually, and results were averaged for each quarterly pinning zone per tree (fig. 2). This method is similar to the line intersect method often used in forest ecology studies (Van Wagner 1968). In wood anatomy studies, vessel area measurements are usually related to a standard area to standardize the data obtained from trees of different ages and sizes or from different parts of a tree for better comparability. In this study, the application of the less time-consuming line intersect method was justified because the material analyzed was formed at the same time of the year, ensured by the quarterly pinning procedure, and because the seedlings were all of exactly the same age and size at the beginning of the experiment.

The vessel diameters were classified into large and small size classes. The limits for T. ciliata were set at 160-80 and 40-20 $\mu \mathrm{m}$, and for $T$. sinensis, at 160-60 and 30-10 $\mu \mathrm{m}$. The remaining vessels were excluded from further analysis. The gaps between the size classes were set deliberately to concentrate on only the largest and smallest vessels and to accentuate the differences between the two size classes. Vessel diameter measurements were converted into values of area, accepting a systematic error due to the assumption that all vessels exhibit a circle shape in cross section. Sums of vessel diameter measurements along individual radii between the pinning wound tissues and the cambium were divided by the length of the corresponding radii in order to relate the sums of vessel areas to the growth increments. The results are presented as box plots of vessel areas and of vessel areas in relation to growth increments of $T$. ciliata and $T$. sinensis for the different treatment groups separately.

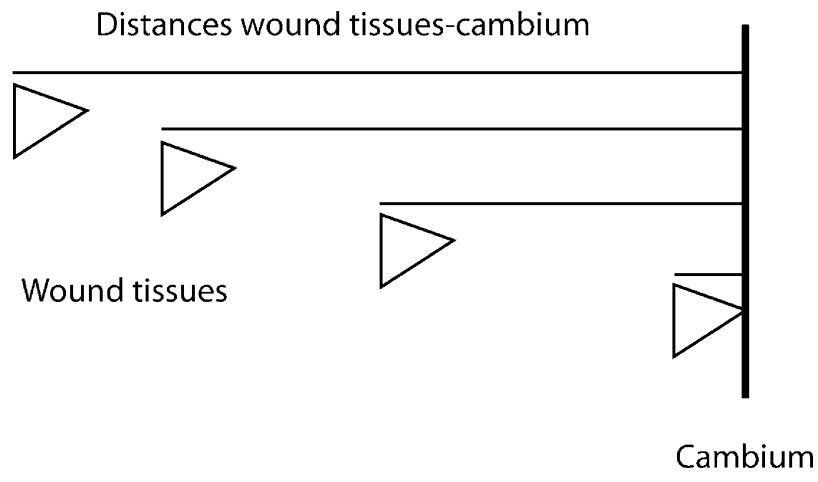

Fig. 2 Diagram of measurements along individual radii between pinning marks and cambium. 
The influence of the different treatments on the vessel areas unrelated and related to the distance between pinning wound tissue and cambium was investigated quantitatively using the software package S-PLUS. The analysis started with an assessment of the normality of the data using histograms. The distribution of the data was skewed and had to be logtransformed in order to conform to a normal distribution before further analysis could be applied. The S-PLUS diagnostic plots (i.e., residual plots) and Cook's distance were used to ensure constant variance and absence of outliers, respectively. ANOVA was conducted for T. ciliata and T. sinensis separately to check the variances of the data between and within groups $\mathrm{X}_{1}-\mathrm{X}_{6}$. Furthermore, a linear model was computed to determine which group means differ from the optimum group $\mathrm{X}_{1}$, and significant values are printed in boldface in tables 2 and 3 .

\section{Results}

\section{Phenology and Ring Formation Data}

Phenological observations and tree-ring formation data are combined in figure 3. The bars indicate periods of semileaflessness $(a)$, full leaflessness $(b)$, leaf flushes $(c)$, and ringboundary formation $(d)$. The figure is subdivided into groups according to treatments $\mathrm{X}_{1}-\mathrm{X}_{6}$. It shows that most trees of Toona sinensis became semileafless and then fully leafless, except for trees $1,3,4,9$, and 12 , which became only semileafless. The deciduous phase in T. sinensis was always followed by a leaf flush and ring-boundary formation. In comparison to groups $\mathrm{X}_{1}$ and $\mathrm{X}_{4}$, the periods of leaf flushes were shorter in $\mathrm{X}_{2}$ and $\mathrm{X}_{3}$ and much shorter in $\mathrm{X}_{5}$ and $\mathrm{X}_{6}$. Most trees of T. sinensis formed ring boundaries after the third pinning in early August, except for tree 1, which did not form a ring at all, and tree 21 , which formed a ring at the end of the experiment.

Table 2

Linear Model of Small- and Large-Vessel Area Data for Toona sinensis and Toona ciliata

\begin{tabular}{|c|c|c|c|c|c|c|}
\hline \multirow[b]{2}{*}{ Treatment group } & \multicolumn{3}{|c|}{ T. sinensis } & \multicolumn{3}{|c|}{ T. ciliata } \\
\hline & Value $(\log )$ & SE & $t$ & Value $(\log )$ & SE & $t$ \\
\hline \multicolumn{7}{|l|}{ Small-vessel data: } \\
\hline $\mathrm{X}_{2}$ & -1.57 & 0.17 & -9.34 & -0.21 & 0.22 & -0.94 \\
\hline $\mathrm{X}_{3}$ & 0.06 & 0.13 & 0.49 & -0.44 & 0.22 & -2.01 \\
\hline $\mathrm{X}_{4}$ & 0.10 & 0.12 & 0.84 & -0.66 & 0.24 & -2.77 \\
\hline $\mathrm{X}_{5}$ & -1.02 & 0.21 & -4.86 & -0.70 & 0.21 & -3.33 \\
\hline $\mathrm{X}_{6}$ & -1.24 & 0.16 & -7.72 & -0.97 & 0.22 & -4.42 \\
\hline$F$ & 41.36 & & & 5.116 & & \\
\hline$P$ & 0 & & & 0.0003 & & \\
\hline \multicolumn{7}{|l|}{ Large-vessel data: } \\
\hline $\mathrm{X}_{2}$ & -0.37 & 0.12 & -3.20 & -0.55 & 0.22 & -2.44 \\
\hline $\mathrm{X}_{3}$ & 0.13 & 0.12 & 1.11 & 0.39 & 0.20 & 1.95 \\
\hline $\mathrm{X}_{4}$ & 0.70 & 0.11 & 6.17 & 0.01 & 0.24 & 0.05 \\
\hline $\mathrm{X}_{5}$ & -0.07 & 0.13 & -0.53 & -0.73 & 0.24 & -3.01 \\
\hline $\mathrm{X}_{6}$ & -0.65 & 0.20 & -3.31 & -0.68 & 0.30 & -2.22 \\
\hline$F$ & 24.65 & & & 7.063 & & \\
\hline$P$ & 0 & & & 0.00001 & & \\
\hline
\end{tabular}

Note. Boldface indicates significant results.
Table 3

Linear Model of Small- and Large-Vessel Area Data in Relation to Each Distance between Pinning Wound Tissue and Cambium for Toona sinensis and Toona ciliata

\begin{tabular}{|c|c|c|c|c|c|c|}
\hline \multirow[b]{2}{*}{ Treatment group } & \multicolumn{3}{|c|}{ T. sinensis } & \multicolumn{3}{|c|}{ T. ciliata } \\
\hline & Value $(\log )$ & SE & $t$ & Value $(\log )$ & SE & $t$ \\
\hline \multicolumn{7}{|l|}{ Small-vessel data: } \\
\hline $\mathrm{X}_{2}$ & 0.45 & 0.18 & 2.53 & 0.72 & 0.29 & 2.45 \\
\hline $\mathrm{X}_{3}$ & 0.03 & 0.13 & 0.23 & -0.55 & 0.29 & -1.91 \\
\hline $\mathrm{X}_{4}$ & 0.20 & 0.13 & 1.52 & 0.40 & 0.31 & 1.28 \\
\hline $\mathrm{X}_{5}$ & 1.13 & 0.22 & 5.14 & 1.13 & 0.28 & 4.10 \\
\hline $\mathrm{X}_{6}$ & 1.98 & 0.17 & 11.72 & 1.96 & 0.29 & 6.76 \\
\hline$F$ & 37.69 & & & 18.55 & & \\
\hline$P$ & 0 & & & 0 & & \\
\hline \multicolumn{7}{|l|}{ Large-vessel data: } \\
\hline $\mathrm{X}_{2}$ & 1.43 & 0.14 & 10.55 & 0.38 & 0.27 & 1.42 \\
\hline $\mathrm{X}_{3}$ & 0.05 & 0.14 & 0.36 & 0.36 & 0.24 & 1.53 \\
\hline $\mathrm{X}_{4}$ & 0.63 & 0.13 & 4.85 & 0.69 & 0.28 & 2.42 \\
\hline $\mathrm{X}_{5}$ & 2.15 & 0.15 & 14.41 & 0.53 & 0.29 & 1.80 \\
\hline $\mathrm{X}_{6}$ & 1.68 & 0.23 & 7.39 & 1.59 & 0.36 & 4.36 \\
\hline$F$ & 68.54 & & & 4.196 & & \\
\hline$P$ & 0 & & & 0.001717 & & \\
\hline
\end{tabular}

Note. Boldface indicates significant results.

Only trees 28 and 31 of the Toona ciliata specimens became fully leafless, while trees $27,32,33,34,35$, and 36 stayed semileafless, although all of them formed a ring boundary. In contrast, trees 25, 26, 29, and 30 had multiple leaf flushes for an extended period of time, but they neither entered leafless periods nor formed a ring. Periods of leaf flushes were shorter in group $\mathrm{X}_{4}$ compared to $\mathrm{X}_{1}$ and $\mathrm{X}_{3}$ and even shorter in $\mathrm{X}_{5}$ and $\mathrm{X}_{6}$. Most trees formed ring boundaries after the third pinning in early August, except for trees 28 and 34, which had already formed a ring after the second pinning in early May.

\section{Diameter and Height Growth Data}

Figure 4 displays height (left) and diameter (right) growth data of $T$. sinensis (gray bars) and T. ciliata (black bars), showing distinct differences between the treatment groups. Toona ciliata generally exhibits larger height and diameter growth in all treatment groups, except for smaller height values in group $\mathrm{X}_{4}$. The largest and smallest values of height and diameter growth in $T$. sinensis are found in groups $\mathrm{X}_{4}$ and $\mathrm{X}_{2}$ or $\mathrm{X}_{3}$ and $\mathrm{X}_{6}$, respectively, while the corresponding groups for $T$. ciliata are $\mathrm{X}_{3}$ and $\mathrm{X}_{4}$ or $\mathrm{X}_{3}$ and $\mathrm{X}_{6}$, respectively. Both height and diameter growth of $T$. sinensis are divided in two: good growth in groups $\mathrm{X}_{1}, \mathrm{X}_{3}$, and $\mathrm{X}_{4}$ and slow growth in $\mathrm{X}_{2}, \mathrm{X}_{5}$, and $\mathrm{X}_{6}$. In contrast, large height increments of $T$. ciliata occur in $\mathrm{X}_{1}-\mathrm{X}_{3}$ and slow growth in $\mathrm{X}_{4}-\mathrm{X}_{6}$. Diameter growth of $T$. ciliata was most limited in groups $\mathrm{X}_{5}$ and $\mathrm{X}_{6}$, less limited in groups $\mathrm{X}_{2}$ and $\mathrm{X}_{4}$, and least limited in groups $\mathrm{X}_{1}$ and $\mathrm{X}_{3}$.

To illustrate the growth activities of both species in time, growth percentages summed to 100 for the individual treatment groups derived from the quarterly diameter measurements over bark are presented (fig. 5). Between February and August, the percentage increases of all $T$. sinensis are low 


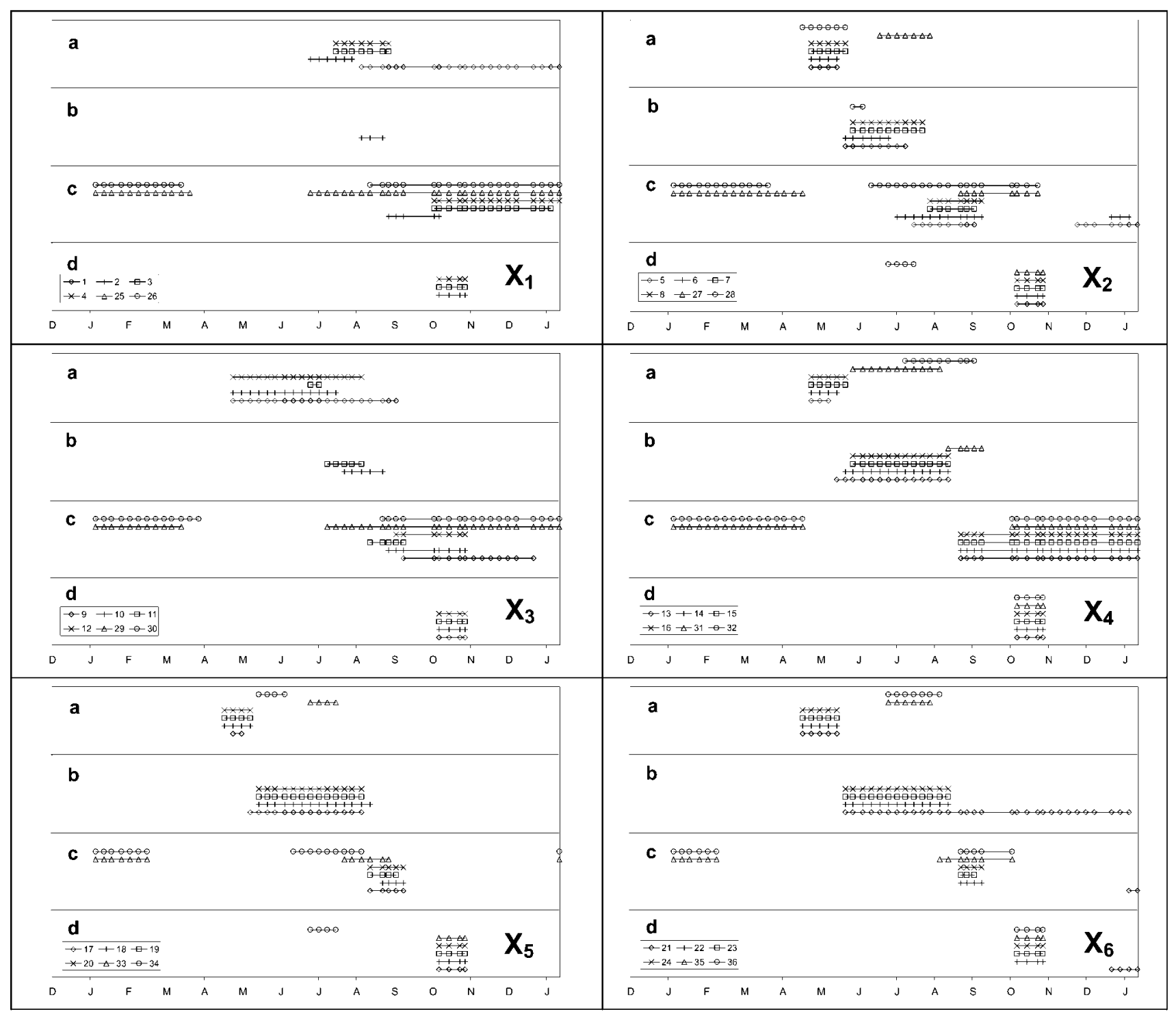

Fig. 3 Monthly periods of semileaflessness $(a)$, leaflessness $(b)$, leaf flushes $(c)$, and tree-ring formations $(d)$ of Toona sinensis (trees 1-24) and Toona ciliata (trees 25-36) in treatment groups $\mathrm{X}_{1}-\mathrm{X}_{6}$.

compared to the other periods, indicating dormancy during this time. Diameter growth of T. ciliata in groups $\mathrm{X}_{1}$ and $\mathrm{X}_{3}$ did not slow, and thus the trees probably did not enter a dormant period. However, trees in group $\mathrm{X}_{6}$ stopped growing completely between May and August, while the specimens of the remaining groups $\mathrm{X}_{2}, \mathrm{X}_{4}$, and $\mathrm{X}_{5}$ exhibit distinct growth reduction only between May and August.

\section{Vessel Characteristics}

The vessel counts in the different treatment groups also vary significantly (fig. 6). Large vessels of $T$. sinensis are most common in groups $\mathrm{X}_{1}-\mathrm{X}_{4}$, while small vessels are most abundant in groups $\mathrm{X}_{1}, \mathrm{X}_{3}$, and $\mathrm{X}_{4}$ but less plentiful in the other groups. In T. ciliata, the most large vessels are found in groups $\mathrm{X}_{1}$ and $\mathrm{X}_{3}$ and the fewest in group $\mathrm{X}_{6}$. The differ- ences of the vessel counts in the small-size class are not as distinct as in the large-size class, with the largest and smallest values displayed in groups $\mathrm{X}_{5}$ and $\mathrm{X}_{4}$, respectively.

Box plots present the distribution of the vessel areas per treatment group (fig. 7). The data of $T$. sinensis for the smallvessel area in groups $\mathrm{X}_{1}, \mathrm{X}_{3}$, and $\mathrm{X}_{4}$ are significantly larger than those in the other groups. In the large-vessel box plot, the vessel area is significantly larger in group $\mathrm{X}_{4}$ than in the other groups. The groups $\mathrm{X}_{1}, \mathrm{X}_{3}$, and $\mathrm{X}_{5}$ display approximately average values, while groups $X_{2}$ and $X_{6}$ show the smallest values.

The box plots for the small-vessel area of $T$. ciliata show decreasing values from groups $\mathrm{X}_{1}$ through $\mathrm{X}_{6}$. The values in group $\mathrm{X}_{1}$ are significantly larger than those in groups $\mathrm{X}_{4}-\mathrm{X}_{6}$, with group $\mathrm{X}_{6}$ exhibiting the smallest values. The box plot 

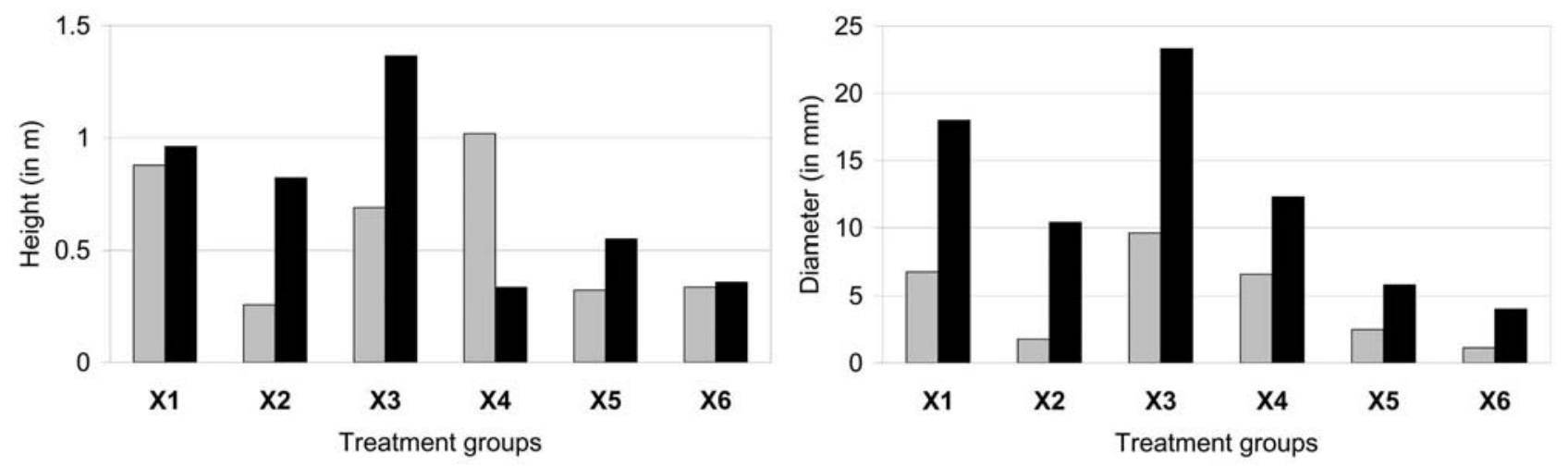

Fig. 4 Total height (left) and diameter (right) growth increments per treatment group of Toona sinensis (gray bars) and Toona ciliata (black bars).

for large vessels shows large values in groups $\mathrm{X}_{1}$ and $\mathrm{X}_{3}$ and smaller values in groups $\mathrm{X}_{2}, \mathrm{X}_{5}$, and $\mathrm{X}_{6}$.

The box plot for the small-vessel area of T. sinensis illustrates that groups $\mathrm{X}_{2}, \mathrm{X}_{5}$, and $\mathrm{X}_{6}$ have the largest ratios of vessel area to diameter increment, a pattern that is repeated even more significantly in the large-vessel class (fig. 8). Similar results are evident in the box plots for $T$. ciliata. The small-vessel area classes show larger values in the minimum treatment groups $\mathrm{X}_{2}, \mathrm{X}_{5}$, and especially $\mathrm{X}_{6}$. Group $\mathrm{X}_{6}$ has significantly larger values than the other groups in the largevessel area class.

The results of the ANOVA indicate that the vessel area measurements in both vessel size classes and species differ significantly between the treatment groups. The linear model computations confirm the graphical results from the box plots. For T. sinensis, significant differences from group $\mathrm{X}_{1}$ in the small- and large-vessel areas are shown for $\mathrm{X}_{2}, \mathrm{X}_{5}$, and $\mathrm{X}_{6}$ and for $\mathrm{X}_{2}, \mathrm{X}_{4}$, and $\mathrm{X}_{6}$, respectively. The optimum group $\mathrm{X}_{1}$ displays significant differences from groups $\mathrm{X}_{3}-\mathrm{X}_{6}$ in the small-vessel class and from $\mathrm{X}_{2}, \mathrm{X}_{5}$, and $\mathrm{X}_{6}$ in the large-vessel class in $T$. ciliata (table 2 ). The values for $T$. sinensis exhibit significant differences in vessel area-diameter increment ratios between $\mathrm{X}_{1}$ and $\mathrm{X}_{2}, \mathrm{X}_{5}$, and $\mathrm{X}_{6}$ in the small-vessel class and between $\mathrm{X}_{1}$ and $\mathrm{X}_{2}, \mathrm{X}_{4}$, and $\mathrm{X}_{6}$ in the large-vessel class. The analogous values for $T$. ciliata show significant differences between $\mathrm{X}_{1}$ and $\mathrm{X}_{2}, \mathrm{X}_{5}$, and $\mathrm{X}_{6}$ and between $\mathrm{X}_{1}$ and $\mathrm{X}_{4}$ and $\mathrm{X}_{6}$, respectively (table 3 ).

\section{Discussion}

Growth experiments were conducted to examine the responses of Toona sinensis and Toona ciliata in terms of phenological behavior, tree-ring formation, height and diameter growth, and vessel characteristics. The results show that the treatments were successful in both species in altering all these aspects, except for tree-ring formation, which was not affected in T. sinensis. However, the treatments had weaker effects on the phenological behavior of $T$. sinensis than on that of T. ciliata. Of the former species, $83 \%$ became leafless, $100 \%$ became semileafless, and $100 \%$ formed a ring boundary, while the respective values for $T$. ciliata were $17 \%$, $50 \%$, and $67 \%$. During the entire experimental period, $33 \%$ of $T$. ciliata did not show any signs of deciduousness and did not form a tree ring, indicating that $T$. ciliata reacted more opportunistically to the optimum treatment than $T$. sinensis. This suggests that at least young trees of $T$. ciliata can adapt to favorite environmental conditions by suppressing dormancy, but $T$. sinensis seems unable to prevent entering it.

The experiment also illustrates that trees of both species that went through at least a semileafless phase during the experiment formed a tree ring as well. Obviously, leaflessness, whether partial or full, can be regarded as an indication of dormancy. In contrast, several leaf flushes without a period of deciduousness in between, as observed in T. ciliata, were not sufficient to induce a ring formation because the
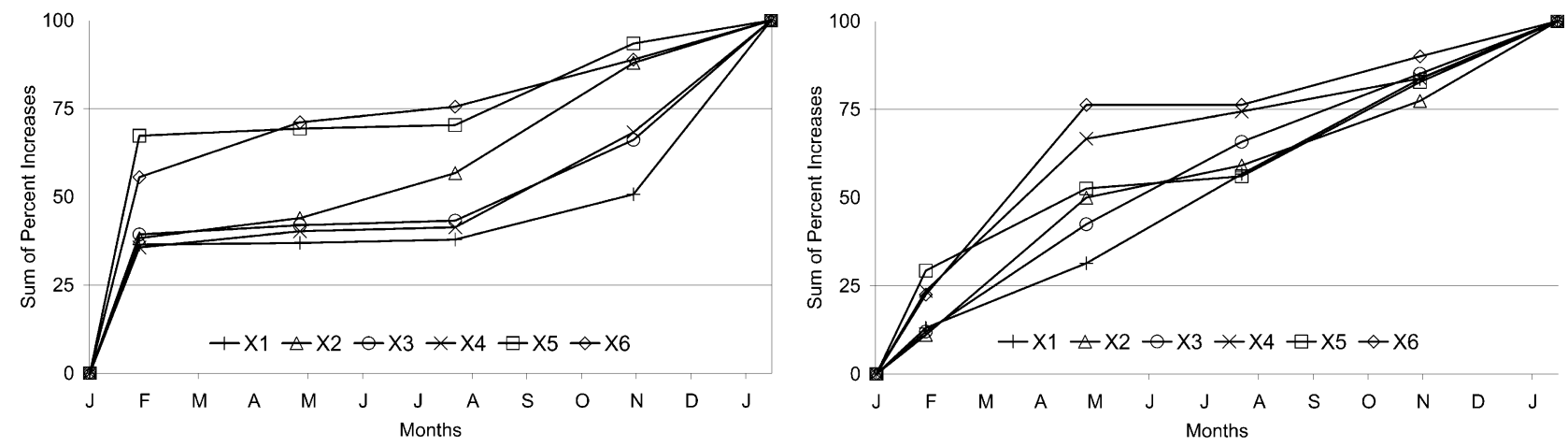

Fig. 5 Percentage diameter increases per treatment group of Toona sinensis (left) and Toona ciliata (right). 

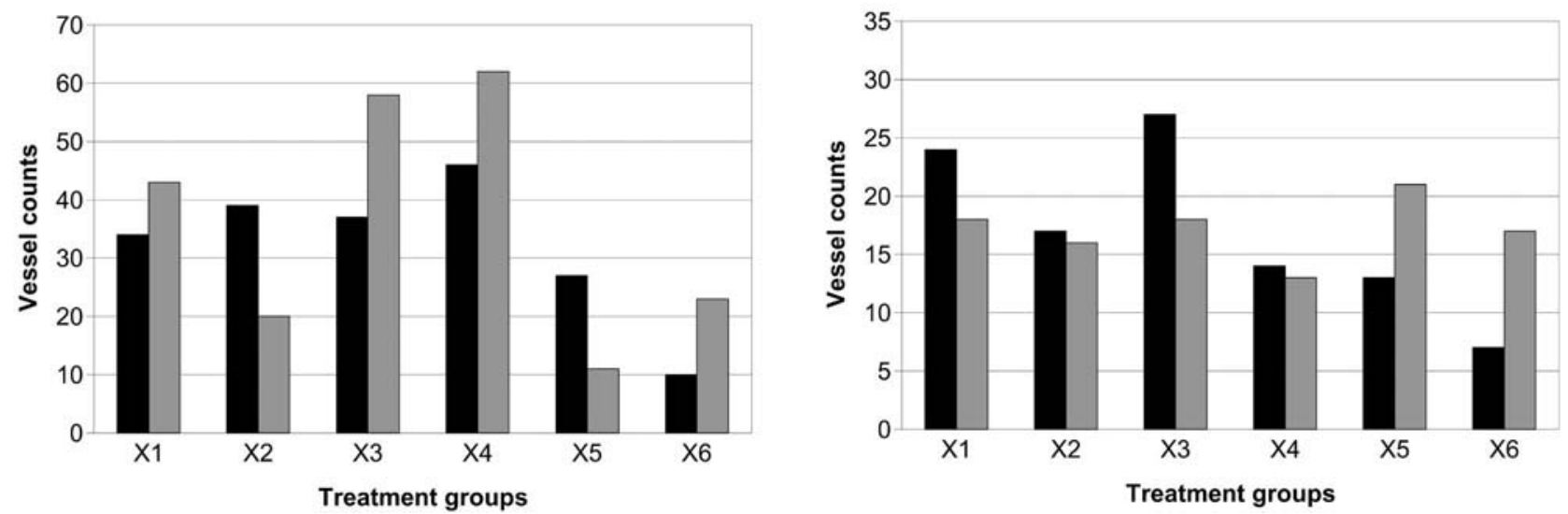

Fig. 6 Total numbers of large (black bars) and small (gray bars) vessels per treatment group for Toona sinensis (left) and Toona ciliata (right).

cambium noticeably did not become dormant between periods of leaf flushes. Furthermore, in shading experiments, specimens of $T$. ciliata produced multiple leaf flushes without forming tree rings (Heinrich and Banks 2006). This affirms results by Chowdhury (1958) and Tomlinson and Craighead (1972), who found that multiple leaf flushes did not result in the same amount of tree rings.

Insect attacks might sometimes result in loss of foliage followed by a leaf flush in order to immediately rebuild the photosynthetic apparatus. Although trees in group $\mathrm{X}_{3}$ showed signs of wilting and shed some leaves, tree-ring formation and growth increments were not affected significantly. This indicates that the treatment in group $\mathrm{X}_{3}$ was not sufficient to reduce diameter growth increments and hence that only heavy insect attacks might result in reduced diameter growth increments. Heinrich and Banks (2006) showed that only total defoliation of $T$. ciliata seedlings was successful in inducing a false tree ring that consisted of a line of vessels embedded in parenchyma cells. The vessels in the boundary of the false tree ring did not markedly differ in size from the vessels formed immediately before and after. Although a collapse of stem growth and formation of false rings might be expected in seedlings, this is less plausible for mature trees in natural forest habitats. Larger trees have the ability to
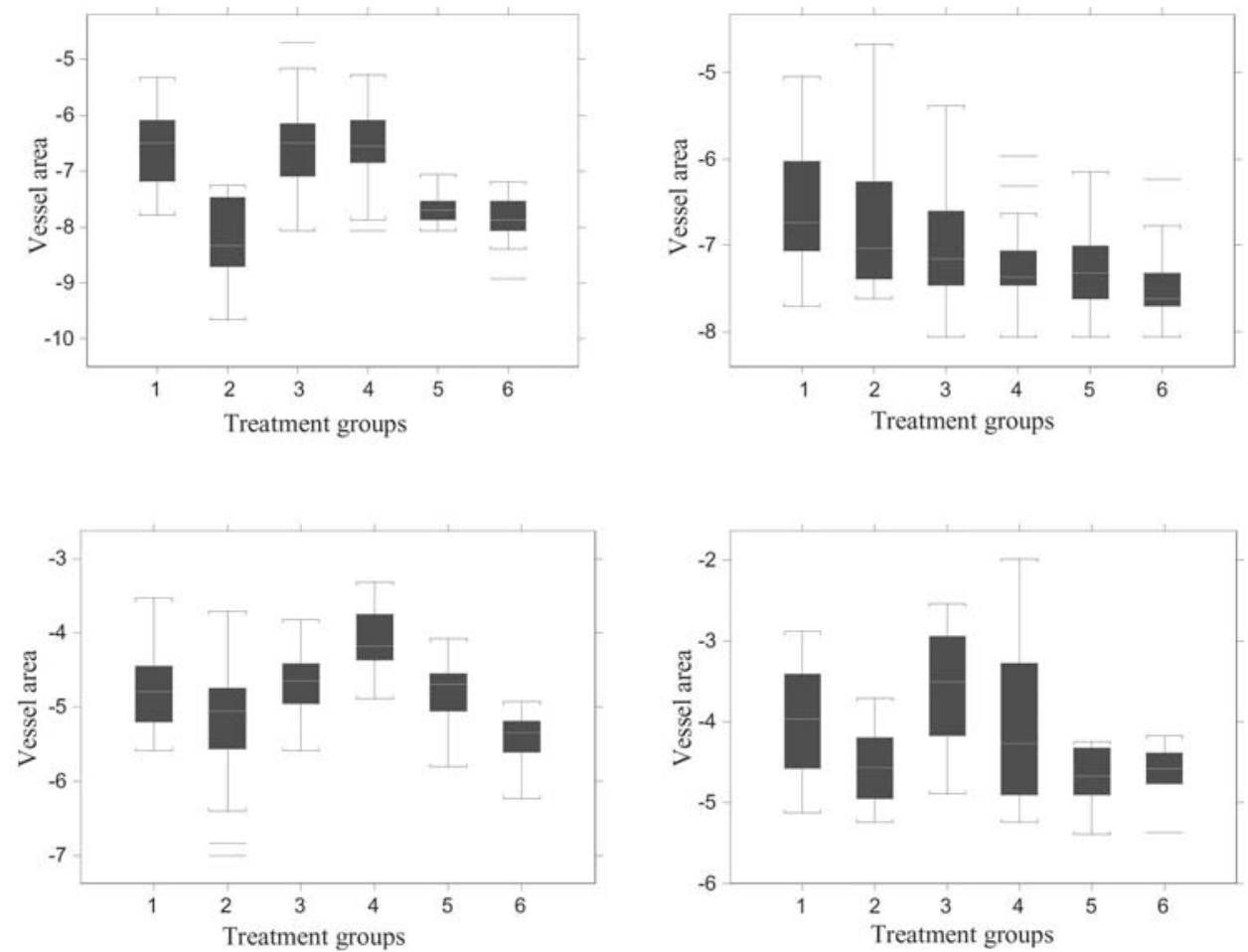

Fig. 7 Box plots of small-vessel (top) and large-vessel (bottom) area per treatment group for Toona sinensis (left) and Toona ciliata (right). 

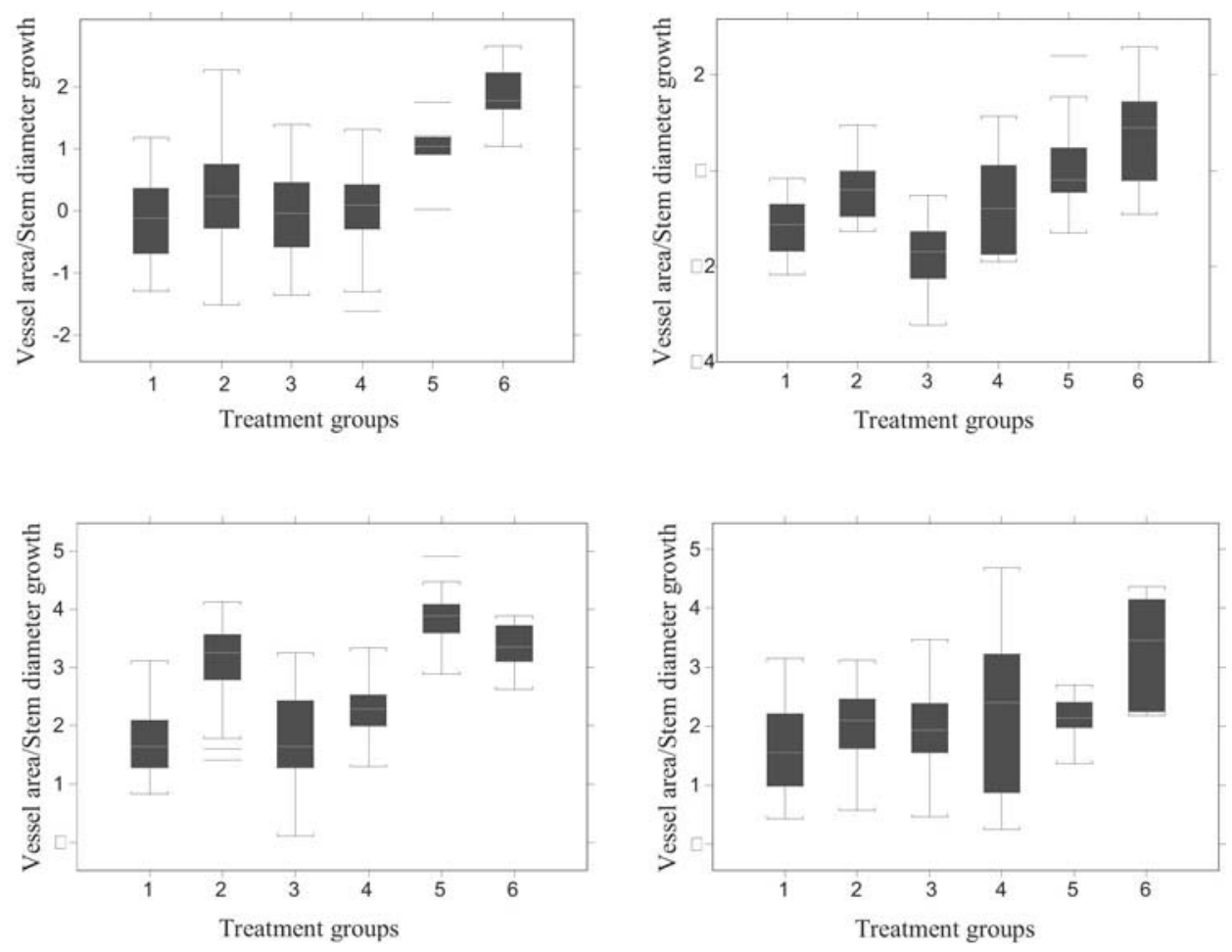

Fig. 8 Box plots of small-vessel (top) and large-vessel (bottom) area in relation to each distance between pinning wound tissue and cambium per treatment group for Toona sinensis (left) and Toona ciliata (right).

mitigate the detrimental effects because of their size. Additionally, especially young trees growing in light conditions or even open-grown trees have been reported to have significantly more borer infestations than mature trees in closedforest habitats (Mo 1996).

The adjustment of the growth periodicity to water availability (Williams et al. 1997; Myers et al. 1998) and temperature (Paliwal et al. 1975; Iqbal and Ghouse 1982) has been observed in other tropical to subtropical tree species. In this study, the different treatments resulted in not only a general change of the phenology patterns but also the possibility of classifying the tree responses into three severity classes. The trees displayed longer periods of deciduousness and shorter periods of leaf flushes the more severe the treatments were; for example, in $T$. sinensis, the deciduous periods were short in the optimum group, longer when watering was limited, and even longer when the supplies of water and fertilizer were limited.

An overall comparison of the height and diameter growth data between the species demonstrates that $T$. ciliata generally grows faster than $T$. sinensis, except under lowtemperature conditions, when $T$. sinensis exhibits larger height growth increments. The analysis also showed that the treatments exerting various forms of stress resulted in growth reactions according to the stress severities. Height increments of $T$. ciliata were smaller when temperatures $\left(\mathrm{X}_{4}\right)$ or supplies of fertilizer $\left(\mathrm{X}_{5}\right)$ were at a minimum than when water was at a minimum $\left(\mathrm{X}_{2}\right)$. This result is in agreement with Boland (2000) that the species is sensitive to both poor soil conditions and frosts. However, the comparison of the T. ciliata height and diameter data in the minimum-water group, $\mathrm{X}_{2}$, and the minimum-temperature group, $\mathrm{X}_{4}$, shows that height growth is relatively more limited by temperature, while diameter growth is more limited by the availability of water. The combination of the minimum-water and minimum-fertilizer treatments in group $\mathrm{X}_{6}$ illustrates that both species have the ability to decrease height and diameter growth dramatically if environmental conditions worsen.

The intraseasonal diameter measurements show, as do the phenological observations, that T. ciliata reacts more opportunistically to optimum conditions than $T$. sinensis. All specimens of the latter species stopped growing for a prolonged period between February and August, while some trees of the former species did not stop growth at all. However, all T. ciliata specimens of groups $\mathrm{X}_{2}, \mathrm{X}_{4}$, and $\mathrm{X}_{5}$ formed tree-ring boundaries, although the current data show slow but continuous growth throughout the normal dormant period between May and August. This suggests that they probably paused their growth for only a very short time, which might have not been detected by this study because the measurement intervals were too large. Since the experiment was conducted with young trees, the results cannot be simply generalized and applied to adult specimens. Coster (1928), Chowdhury (1961), Fahn et al. (1981), and Tomlinson and Longman (1981) found that younger trees have less distinct periodic growth patterns and that they continuously develop new shoots under good growing conditions, thereby keeping up plant hormone levels (Atwell et al. 1999). This inhibits the cambium from going into dormancy and might result in missing rings. However, the above studies also observed that false rings in older trees were less common. Therefore, during 
future tree-ring analysis, young material of $T$. ciliata should be handled with care in this regard. Nevertheless, the results are encouraging for future dendroclimatological investigations of the species in tropical to subtropical Australasia because they suggest that the tree rings of both species are sensitive to precipitation and temperature, depending on appropriate site selection (Cook and Kairiukstis 1990).

As with phenology, height and diameter growth and the vessel characteristics of both species were also influenced in the course of the experiment. In all treatment groups and in both vessel size classes, samples of $T$. sinensis contained more but smaller vessels than samples of $T$. ciliata. Several studies (Carlquist 1966) have reported that water availability exhibits a positive correlation with vessel size and a negative correlation with vessel numbers. However, in the current data set, only the measurements for T. ciliata follow this pattern. In $T$. ciliata, large vessels are relatively more abundant than small vessels in the optimum groups, $\mathrm{X}_{1}$ and $\mathrm{X}_{3}$, than in the minimum groups, $\mathrm{X}_{5}$ and $\mathrm{X}_{6}$. In the medium-stressed groups, $\mathrm{X}_{2}$ and $\mathrm{X}_{4}$, total counts of large and small vessels are similar. Generally, T. sinensis contains relatively more small vessels than large vessels, except in groups $\mathrm{X}_{2}$ and $\mathrm{X}_{5}$. This pattern suggests that the species has adapted its physiology to somewhat drier climatic conditions compared with T. cili$a t a$, which usually grows under more humid conditions.

The comparison of absolute vessel areas (fig. 7) with vessel areas in relation to intraseasonal diameter increments (fig. 8) shows a reversed distribution of the boxes in the box plots due to extremely reduced diameter increments in the minimumsupply treatment groups. This suggests that diameter growth changed relatively more than vessel dimensions. Trees in the minimum treatment groups adjusted to restricted growth conditions relatively more by reducing the amount of latewood formed. Phipps (1982) showed that latewood varied considerably more than earlywood in ring-porous trees from eastern North America. In ring-porous trees, the latewood portion of the annual tree ring is usually much larger than the part covered by the earlywood, and hence the effects of such an adjustment on the macroscopic occurrence of the tree-ring structure can be quite dramatic. The macroscopic impression is a highly porous wood of low density, implying that the tree grew under good conditions, while in fact the opposite was true. This phenomenon has been observed in a preliminary study of increment core samples taken from mature trees growing in tropical rain forests of Queensland, Australia (Heinrich and Banks 2006). The results imply that during a prolonged period of poor growing conditions, for example, extreme droughts in eastern Australia during the 1990s and in the early years of the twenty-first century, the wood anatomical result in T. ciliata would be several narrow rows of earlywood vessels, each representing one tree ring, with few to no latewood cells between. If such narrow ring patterns occur only occasionally because of extreme climate conditions, they act as pointer years and thus help during crossdating. However, if too many narrow tree rings are formed because of other nonclimatic restrictions, for example, competition or increasingly limited nutrient supply, crossdating will be hindered.

\section{Acknowledgments}

We would like to thank "Lui" Ljube Cvetkoski and Luke Wensing of the School of Botany and Zoology, Australian National University, for their great support during the growth experiment, and the Electron Microscopy Unit of the Australian National University for permission to use its facilities. Ingo Heinrich received $\mathrm{PhD}$ scholarships from the Australian National University, the Cooperative Research Centre for Greenhouse Accounting, and the German Academic Exchange Service (DAAD).

\section{Literature Cited}

Ajmal S, M Iqbal 1987 Seasonal rhythms of structure and behaviour of vascular cambium in Ficus rumphii. Ann Bot 60:649-656.

Alvim PD 1964 Tree growth and periodicity in tropical climates. Pages 479-495 in MH Zimmermann, ed. The formation of wood in forest trees. Academic Press, New York.

Amobi CC 1972 Multiple wood growth and multiple wood formation in seedlings of Monodora tenuifolia Benth. Ann Bot 36: 199-205.

1973 Periodicity of wood formation in some trees of lowland rain forest in Nigeria. Ann Bot 37:211-218.

1974 Periodicity of wood formation in twigs of some tropical trees in Nigeria. Ann Bot 38:931-936.

Atwell BJ, PE Kriedemann, CGN Turnbull, eds 1999 Plants in action: adaptation in nature, performance in cultivation. McMillan Education Australia, South Yarra.

Baas P 1973 The wood anatomical range in Ilex and its phylogenetic and systematic significance. Blumea 21:193-258.

Barajas-Morales J 1985 Wood structural differences between trees of two tropical forests in Mexico. IAWA Bull 6:355-364.

Bauch J, O Dünisch 2000 Comparison of growth dynamics and wood characteristics of plantation-grown and primary forest Carapa guianensis in Central Amazonia. IAWA J 21:321-333.
Boland DJ 2000 Toona ciliata M. Roemer. Electronic forestry compendium. CAB International, Wallingford.

Boland DJ, MIH Brooker, GM Chippendale, N Hall, BPM Hyland, RD Johnston, DA Kleinig, JD Turner 2002 Forest trees of Australia. CSIRO, Collingwood. 687 pp.

Breitsprecher A, JS Bethel 1990 Stem growth periodicity of trees in a tropical wet forest of Costa Rica. Ecology 71:1156-1164.

Carlquist S 1966 Wood anatomy of Compositae: a summary, with comments on factors controlling wood evolution. Aliso 6: 25-44.

Chowdhury KA 1958 Extension and radial growth in tropical perennial plants. Pages 10-20 in P Maheshwari, ed. Modern developments in plant physiology. Delhi University, Delhi.

1961 Growth rings in tropical trees and taxonomy. Abstract 280, 10th Pacific Science Congress. Pacific Science Association, Honolulu.

Cook ER, LA Kairiukstis 1990 Methods of dendrochronology: applications in the environmental sciences. Kluwer Academic, Dordrecht. 394 pp.

Coster C 1923 Lauberneuerung und andere periodische Lebensprozesse in dem trockenen Monsun Gebiete Ost-Javas. Ann Jard Bot Buitenzorg 33:117-189. 
1927 Zur Anatomie und Physiologie der Zuwachszonen und Jahresringbildung in den Tropen. I. Ann Jard Bot Buitenzorg 37: 49-161.

1928 Zur Anatomie und Physiologie der Zuwachszonen und Jahresringbildung in den Tropen. II. Ann Jard Bot Buitenzorg 38: 1-114.

Dadswell HE, HD Ingle 1954 The wood anatomy of New Guinea Nothofagus Bl. Aust J Bot 2:141-153.

Daubenmire R 1972 Phenology and other characteristics of tropical semi-deciduous forest in north-western Costa Rica. J Ecol 60: 147-170.

Edmonds JM 1995 Toona. Pages 358-371 in DJ Mabberley, CM Pannell, AM Sing, eds. Meliaceae. Flora Malesiana, ser 1. Rijksherbarium/Hortus Botanicus, Leiden.

Edmonds JM, M Staniforth 1998 Toona sinensis. Curtis's Bot Mag 15:186-193.

Fahn A, J Burley, KA Longman, A Mariaux, PB Tomlinson 1981 Possible contributions of wood anatomy to the determination of the age of tropical trees. Pages 31-54 in FH Bormann, G Berlyn, eds. Age and growth rate of tropical trees: new directions for research. Proceedings of the workshop on age and growth rate determination for tropical trees. Yale University, New Haven, CT.

Fahn A, E Werker 1990 Seasonal cambial activity. Pages 139-157 in M Iqbal, ed. The vascular cambium. Research Studies, Taunton.

Floyd AG 1979 NSW rainforest trees. VIII. Forestry Commission of New South Wales, Sydney.

Frankie GW, HG Baker, PA Opler 1974 Comparative phenological studies of trees in tropical wet and dry forests in the lowlands of Costa Rica. J Ecol 62:881-919.

Fujii T, AT Salang, T Fujiwara 1999 Growth periodicity in relation to the xylem development in three Shorea spp. (Dipterocarpaceae) growing in Sarawak. Pages 131-137 in R Wimmer, R Vetter, eds. Tree ring analysis: biological, methodological and environmental aspects. CAB International, Wallingford.

Ghouse AKM, S Hashmi 1979 Cambium periodicity in Polyalthia longifolia. Phytomorphology 29:64-67.

Heinrich I, JCG Banks 2006 Tree-ring anomalies in Toona ciliata. IAWA J 27:213-231.

Iqbal M 1981 A decade of research in plant anatomy at Aligarh (1971-1980). Aligarh Muslim University, Aliargh.

Iqbal M, AKM Ghouse 1982 Environmental influence on growth activities of Prosopis spicigera. Pages 387-393 in PK Koshla, ed. Improvement of forest biomass. Indian Society of Tree Scientists, Solan.

Koriba K 1958 On the periodicity of tree-growth in the tropics, with reference to the mode of branching, the leaf fall, and formation of resting bud. Gard Bull Singapore 17:11-81.

Kuroda K 1986 Wound effects on cytodifferentiation in the secondary xylem of woody plants. Wood Res 72:67-118.

Kuroda K, K Shimaji 1984 Wound effects on xylem cell-differentiation in a conifer. IAWA Bull 5:295-305.

1985 Wound effects on cytodifferentiation in hardwood xylem. IAWA Bull 6:107-118.

Lindorf H 1994 Eco-anatomical wood features of species from a very dry tropical forest. IAWA J 15:361-376.

Liphschitz N, Y Waisel 1970 Effects of environment on relations between extension and cambial growth of Populus euphratica Oliv. New Phytol 69:1064.

Mariaux A 1967 Les cernes dans les bois tropicaux Africans: nature et périodicité. Rev Bois For Trop 114:23-37.

Mo J 1996 Some aspects of the ecology and behaviour of the Australian red cedar tip moth, Hypsipyla robusta Moore. PhD diss. Australian National University, Canberra.

Mo J, MT Tanton, FL Bygrave 1997a Temporal and inter-tree variations of attack by Hypsipyla robusta Moore (Lepidoptera:
Pyralidae) in Australian red cedar (Toona australis (F. Muell.) Harmes). For Ecol Manag 96:139-146.

—_ $1997 b$ Within-tree distribution of attack by Hypsipyla robusta Moore (Lepidoptera: Pyralidae) in Australian red cedar (Toona australis (F. Muell.) Harmes). For Ecol Manag 96:147-154. Myers BA, RJ Williams, I Fordyce, GA Duff, D Eamus 1998 Does irrigation affect leaf phenology in deciduous and evergreen trees of the savannas of northern Australia? Aust J Ecol 23:329-339.

Njoku E 1963 Seasonal periodicity in the growth and plant development of some forest trees in Nigeria. I. Observation on mature trees. J Ecol 51:617-624.

1964 Seasonal periodicity in the growth and development of some forest trees in Nigeria. II. Observation on seedlings. J Ecol 52: 19-26.

Nobuchi T, Y Ogata, S Siripatanadilok 1995 Seasonal characteristics of wood formation in Hopea odorata and Shorea henryana. IAWA J 16:361-369.

Paliwal GS, NVSRK Prasad 1970 Seasonal activity of cambium in some tropical trees. I. Dahlbergia sissoo. Phytomorphology 20:333-339.

Paliwal GS, NVSRK Prasad, VS Sajwan, SK Aggarwal 1975 Seasonal activity of cambium in some tropical trees. II. Polyalthia longifolia. Phytomorphology 25:478-484.

Phipps RL 1982 Comments on interpretation of climatic information from tree rings, Eastern North America. Tree-Ring Bull 42:11-22.

Priya PB, KM Bhat 1999 Influence of rainfall, irrigation and age on the growth periodicity and wood structure in teak (Tectona grandis). IAWA J 20:181-192.

Reich PB, R Borchert 1984 Water stress and tree phenology in a tropical dry forest in the lowlands of Costa Rica. J Ecol 72:61-74.

Rivera G, R Borchert 2001 Induction of flowering in tropical trees by a 30-min reduction in photoperiod: evidence from field observations and herbarium specimens. Tree Physiol 21:201-212.

Sass U, W Killmann, D Eckstein 1995 Wood formation in two species of Dipterocarpaceae in peninsular Malaysia. IAWA J 16: 371-384.

Schöngart J, MTF Piedade, S Ludwigshausen, V Horna, M Worbes 2002 Phenology and stem-growth periodicity of tree species in Amazonian floodplain forests. J Trop Ecol 18:581-597.

Shiokura T 1989 A method to measure radial increment in tropical trees. IAWA Bull 10:147-154.

Simon SV 1914 Studien über die Periodizität der Lebensprozesse der in dauernd feuchten Tropengebieten heimischen Bäume. Jahrb Wiss Bot 54:71-187.

Strasburger E, P Sitte, EW Weiler, JW Kadereit, A Bresinsky, C Körner 2002 Lehrbuch der Botanik für Hochschulen. Spektrum Akademischer, Heidelberg. 1123 pp.

Tomlinson PB, FCS Craighead 1972 Growth-ring studies on the native trees of subtropical Florida. Pages 39-51 in AKM Ghouse, M Yunus, eds. Research trends in plant anatomy. Tata McGraw-Hill, New Delhi.

Tomlinson PB, KA Longman 1981 Growth phenology of tropical trees in relation to cambial activity. Pages 7-19 in FH Bormann, G Berlyn, eds. Age and growth rate of tropical trees: new directions for research. Proceedings of the workshop on age and growth rate determination for tropical trees. Yale University, New Haven, CT.

Van Wagner CE 1968 The line intersect method in forest fuel sampling. For Sci 14:20-26.

Volkens G 1903 Laubwechsel tropischer Bäume. Gartenflora 52: 591-598.

Wheeler EA, P Baas 1993 The potentials and limitations of dicotyledonous wood anatomy for climatic reconstruction. Paleobiology 19:487-498.

Wilkins AP, S Papassotiriou 1989 Wood anatomical variation of Acacia melanoxylon in relation to latitude. IAWA Bull New Ser 10: 201-207. 
Williams RJ, BA Myers, WA Muller, GA Duff, D Eamus 1997 Leaf phenology of woody species in Australian tropical savanna. Ecology 78:2542-2558.

Wolter KE 1968 A new method for marking xylem growth. For Sci 14:102-104.
Woodcock DW, CM Ignas 1994 Prevalence of wood characters in Eastern North America: what characters are most promising for interpreting climates from fossil wood? Am J Bot 81:1243-1251.

Wright SJ, FH Cornejo 1990 Seasonal drought and leaf fall in a tropical forest. Ecology 71:1165-1175. 